\title{
Entrepreneurship Education for Industrial Professional: The Influence of Communication, Teamwork, Leadership and Innovative Soft Skill on Job Performance
}

\author{
Ahmad, F.S., Velu, B. K.D.V., Zaidin, N., Shariff S.A.
}

\begin{abstract}
Education for 21st century should be different from 20th Century. After all we have leapt from to the Industrial Revolution (IR) 2.0 to 4.0 in between these two periods. Yet most educators of integrated disciplines such as entrepreneurship education for engineers in tertiary institutions are those who were trained in 20th century with mechanistic approach focusing on feasibility and viability of bureaucratic environment with less focus on soft skills qualities. The advancement of IR 4.0 has led a new drive for educational transformation with far greater needs to produce agile graduates with strong entrepreneurial soft skills qualities of good communication, teamwork, leadership and innovativeness (CTLI). This paper discusses the perceived mastery of CTLI skills among engineers and assess whether these skills significantly influence their job performance. A quantitative research was conducted on engineers working in a regional oil and gas corporation located in East Malaysia. The gathered data is analyzed via SPSS 22 and the results indicate that most engineers with good mastery of CTLI skills perform better at workplace. This finding necessitates changes to be made in major aspects of entrepreneurship education including policy, content and delivery where the mechanistic approach focusing on feasibility and viability focused must be transformed into the more organic approach that engage, empower, appreciate and connects talents through vibrant, creative, and human-centered education. Although it will be a great challenge for educators to integrate the traditional field of knowledge within the IR4.0 framework, the integration of CTLI experience through entrepreneurship education would produce better equipped technical graduates.
\end{abstract}

Keywords: entrepreneurial qualities, industrial professional, IR 4.0 entrepreneurship education, soft skills

\section{INTRODUCTION}

According to the Quality Assurance Agency for Higher Education of United Kingdom (QAA 2012), education is a transdisciplinary process of equipping graduates with enhanced capacity to innovate or generate new ideas with strong employability qualities. In United States, since early 2000, entrepreneurship education particularly for technical students has been regarded as integral in order to equip students with skills and qualities necessary in new economic realities such as reengineering, mergers, technology

Revised Manuscript Received on November 11, 2019.

Ahmad, F.S., Azman Hashim International Business School, Universiti Teknologi Malaysia, Kuala Lumpur, Malaysia

Velu, B. K.D.V.,Azman Hashim International Business School, Universiti Teknologi Malaysia, Kuala Lumpur, Malaysia

Zaidin, N. Azman Hashim International Business School, Universiti Teknologi Malaysia, Kuala Lumpur, Malaysia.

Shariff S.A., Razak Faculty of Technology and Informatics, Universiti Teknologi Malaysia, Kuala Lumpur, Malaysia revolution, new innovations and other complexities affecting career path (Duval C N, 2013). The focus of entrepreneurship education for technical graduates was earlier illustrated by Okudan and Rzasa (2004) in discussing technology innovation education using project based approach where the study highlighted the major revision by Penn State University in enhancing their entrepreneurship education which include facilitating of skills and qualities in the area of communication, teamwork, leadership and innovativeness (CTLI). These skills are crucial in addition to motivation and business planning focus.

In another perspective, entrepreneurship education for 21 st century should be different from 20th Century. After all we have leapt from to the Industrial Revolution (IR) 2.0 to 4.0 in between these two periods. Yet most educators of integrated disciplines such as entrepreneurship education for engineers in tertiary institutions are those who were trained in 20th century with mechanistic approach focusing on feasibility and viability within bureaucratic environment. A survey on the perceived quality of Malaysian graduates by 200 top employers highlighted that communication skill, creative and critical thinking, analytical skill, problem solving and ability to work independently as among the skill deficits in fresh graduates affecting their employability (Talentcorp, 2014). IR 4.0 drives a new need for entrepreneurship educational transformation with far greater expectation towards preparing graduates with strong entrepreneurial mind and skills with higher qualities of CTLI. This has necessitated profound changes to be made in major aspects of entrepreneurship education including policy, content and delivery of Education 4.0 with emphasis on innovations and at the same time be able to produce graduates with high capacity to innovate. Thus, the intended education must train students to produce innovations, to be more analytics, agile and future ready (Abdul Haseeb, 2018; Sani 2018). Industry skills preference for engineers has changed over time due to rapid globalization and industrial revolutions demand for multi-talented workers. Technical skills used to be the major determining criteria for the engineering employability. However, today, soft skills are also perceived as a critical requirement when it comes to hiring engineers. The skills gap is evident and became more prevalent in the rising unemployment rates in Malaysia. In other words, entrepreneurial qualities are regarded as important in a broader job performance context and not necessarily for new entrepreneurs with fresh start-ups.

Entrepreneurship education 4.0 must address the issue on the grey and mechanistic approach of entrepreneurship content that just focusing on feasibility and viability aspects of running businesses into a

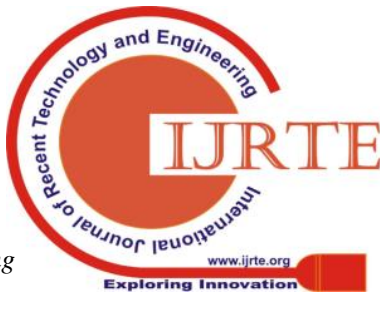




\section{Entrepreneurship Education for Industrial Professional: The Influence of Communication, Teamwork, Leadership and Innovative Soft Skill on Job Performance}

more organic approach that engage, empower, appreciate and connects talents through vibrant, creative, and humancentered education. The improvements on entrepreneurship education for industrial professionals should be carried out with a guided input from the professional workforce based on their actual experience with regard to entrepreneurial soft skills such as CTLI qualities and how these affects their job performance. This paper will look into the engineers' soft skill proficiency in terms of CTLI and its influence on their performance. The findings are expected to justify the necessities of cultivating entrepreneurial soft skill for technical graduates.

\section{LITERATURE REVIEW}

The efforts to produce well-rounded graduates have been one of the Malaysia government mission in the past thirteen years towards producing more competitive human capital in the nation. In 2006, universities and other higher learning institutes developed a framework for effective implementation of soft skills (Shakir, 2007). The directive was given to all public higher learning institutes to include soft skills in their curricular across disciplines due to growing concern over the number of unemployed graduates lacking communication, problem solving and thinking skills.

To prepare the graduates for employment, higher learning institutes play an important role in integrating traits/attributes of soft skills into the technical skills learning. The effectiveness of infusing soft skill in technical learning is not easy as it may sound. This is due to absence of standard or absolute measurement to rate the students' mastery or improvement in soft skill. However, the common indicator that is referred to in indicating acceptable mastery of the soft skills is the employability rate of graduates. Employability rate is the ability of fresh graduates in getting a job that is in accordance to their specialization area. Interview process normally includes questions or activities to gauge CTLI skills. In Malaysia, employability rate is currently being used as an indicator to portray the competitiveness and quality of graduates exiting from particular higher learning institution.

\section{Graduates Attributes in Malaysia}

Graduates attributes refer to the set of skills or quality that need to be gained and developed by the student at tertiary education institutes (Hanapi \& Nordin, 2014). Quality of graduates determines the quality of human capitals in a country. The interrelation between human capital development and economic globalization is crucial to advance and meet the globalization needs and its challenges for developing nations. Thus, innovative and skilled labors are critical requirement for sustainable competitive advantage and strong economic development. To realize the aspiration of Malaysia to be a fully developed nation by 2050, higher education contributions in producing capable graduates in the country is highly imperative. Skilled graduates will form the innovative and high productive workforce that drive towards the nation's growth. It is also equally important to stress that education system needs to be relevant, dynamic, and highly efficient to meet the industry needs.

Cumulative Grade Average Point (CGPA) has been widely used in Malaysia has been used in Malaysia to assess students' performance in education. CGPA is calculated by dividing cumulative grade points for total subjects (determined by multiplying the grade values with credit hours in the particular semester) with the cumulated attempted hours (Alfan \& Othman, 2005). However, the belief that good academic achievement i.e. high CGPA will secure a decent job in the industry has become a myth as employers expect candidates to pose additional skills i.e. soft skills attributes on top of knowledge and skills attained at universities. Previous research shows that there is a negative weak relationship exist between CGPA and performance of employees at work. This indicates that an excellent student in university does not necessarily yields outstanding performance at work (Junaidah Hashim, 2012).

On the other hand, perception of having a degree as the ticket to secure a job may no longer be a valid assumption. This is mainly due to many employers are seeking for various types of experience in the fresh graduates to fit into their organization and business environment (Junaidah Hashim, 2012). Nik Hairi et al. (2012) found that majority of employers were opting for graduates with degree qualification. However, they tended to hire the candidates based on skilled proficiency rather than academic excellence as per CGPA. Employers identified graduates' strengths "lies in their IT skills, interpersonal skills and honesty/integrity" while areas for improvement highlighted in leadership skills which include "adaptability, creative/innovative skills, communication skills (verbal and written), confidence/positive self-image, and enthusiasm/motivation" (Hoo Q. C., Nasurdin, Chai, \& Ignatius, 2009).

The industry widely acknowledged that Malaysian graduates are good academically, but still need to improve on their communication and analytical thinking skills. This has been highlighted over the time as a challenge for the industry and nation to embrace tough environment and economic globalization (Darmi \& Albion, 2013). The above was further supported by Professor Dwight H. Perkins, the Harold Hitchings Burbank Professor of Political Economy, Emeritus, at the Faculty of Arts and Sciences of Harvard Kennedy School. He mentioned that "Malaysian universities are not producing the type of graduates to drive innovation and research and development (R\&D)" which are critical for the nation advancement (The Sun Daily, 2017). Similar message was shared by ISE chief executive officer, Stephen Isherwood. He stated that the pace of the workplace is ever increasing thus graduates need to ensure their skills and ability must be able to secure and thrive as their career develops (News Straits Times, 2018). The phenomena of employers' preference beyond academic transcript and unemployment phenomena stirred government and education institutions to relook into the overall curriculum structure to produce future graduates with better employability skills. The primary role of higher educational institutes is to transfer the technical knowledge to their students. With the recent wave of skill preference, the institutions are still finding ways to improve their curriculum structure to fit both skills expectation on their students. 


\section{Employability Skills for Engineers}

The term 'employability' is no longer alien when it comes to the researches that are associated with graduate skills studies. Employability is simply referring to the set of skills that are expected by employers in forming the workforce in the industry or organization to deliver the expected performance and results. It can also be identified as one of the valuable tools to increase mobility and income (Sisodia and Agarwal, 2017). Yorke (2006) mentioned that employability is a set of skills and knowledge that provides higher probability to secure and be successful in the chosen field of job. In general terms, it could be referred as one having the abilities and skills to find employment or obtain new employment as, and when, required.

The changing economic landscape and rapid technological advancement has necessitated demand for intensified and high skilled labor force in the country. According to Deputy Women, Family and Community Development Minister Hannah Yeoh, Malaysia needs 500,000 scientists and engineers by 2020 (The Malaysian Insight, 2018). With the demand for engineers is sky rocketing in Malaysia, ensuring good qualities of engineering graduates with adequate employability skills is paramount to sustain economic growth. Engineering jobs require high technical skills to perform the core tasks. The industry has acknowledged that local engineering graduates possessed excellent academic knowledge and technical skills (Yuzainee, Omar, \& Zaharim, 2010). However, the service sector did not overlook the importance of soft skills in their hiring process. The truth is, engineering graduates at present time experience difficulties and challenges in getting employed (Leaderonomics, 2017). This was not the case in early times where engineers were highly demanded for their competency and capability in technical areas.

Yuzainee et al. (2010) concluded that Malaysian employers prefer engineering graduates that have "excellent communication skills, excellent teamwork ability and good attitude toward professionalism" as their top three requirement. This finding was further supported by the research done by Zaharima et. al (2012) that shows Malaysian employers in the engineering sector prefer graduates with good communication skills and work well in group. Their findings also emphasized that engineering graduates need to improve their soft skills as acquiring a good degree does not differentiate them in today's job hunting market.

Recently, Jobstreet (2017) outlined that 5 soft skills were identified for engineering graduates in Malaysia to stand out and perform distinctively among others. The first skill that ranked among the five was social. Social skill is referring to the ability to connect with each other via effective communication skills. Leadership skill climbed to the second rank. This skill is highly necessary to lead, manage and harness any conflict resolutions. Creativity was identified to be the fourth skill to be nurtured among engineers as it allows to perceive a problem with innovative mind and solutions. This particular attribute was highlighted as an important skill in order to be a high performing engineer. Collaboration or teamwork abilities was the next skill on the line. The fact that most engineering projects involve few disciplines or specialization is well knows due to nature of engineering projects. Thus, engineers must be able to collaborate and work as a team to deliver the intended output at the most safest, highly productive and cost effective manner. The last skill mentioned was adaptability. Engineers must be able to progress parallel with global trends of technology and information and responsive to the changing economic environment.

\section{Soft Skill}

Soft skills or also known as generic skills are not technical skills. It has no relation with the content of an individual knowledge in a specific area or discipline. Soft skills closely identified to an individual's interpersonal skills and behavioral skills that are necessary in applying the technical skills and knowledge at workplace (Rainsbury, Hodges, \& Burchell, 2001).

Various studies suggest the below as top soft skills thirst by the industry employers:

\section{i. Communication Skill (Verbal \& Written)}

Ability to interact and convey the messages in the right pitch across organization is imperative for effective communication. Communication skills refer to the individual 'that adapts communication to listeners' needs, checking listeners' understanding by listening attentively to the complete message, restating and questioning listeners to ensure comprehension"(Ngang , Mohamed , \& Kanokorn, 2015). Employee shall be able to speak clearly, respectfully to any typology speakers. The body language, gesture and tone used during the interaction shall be appropriate when communicating at different level and contexts. The individual must also be able to present information that technical and non-technical clearly in a style that easily understood.

\section{ii. Teamwork}

Ability to work with others from diverse backgrounds (Williams, 2015). The collaborative spirit must be nurtured with respectful attitude towards each other to achieve the common goals. Many studies suggest that teamwork could improve organization productivity. However, it takes great effort to tolerate, contribute and sustain the momentum and collaboration spirit for shared success.

\section{iii. Leadership Abilities}

Leadership skill is generally referring to the capacity to lead he/she (individual) and also a group of people to work towards a common goal. Individuals with leadership abilities are able inspire or influence the rest of the people around them via giving and receiving feedback, delegating tasks and portray good behavior and ability to solve any disputes or problems. An effective leadership will carefully consider critical leadership aspects such as cultural knowledge, teamwork, motivation and team management (Yahaya, Maalip, Yahaya, \& Theng, 2018). "Leadership abilities is important in organizations because it consists of people who have human capital, social capital, and positive psychological capital" (Hendarmana \& Tjakraatmadjab, 2012).

\section{iv. Innovativeness}

Creative and innovative is the ability to solve routine and non-routine problems that arises in organization in order to achieve the business goals. Creativity is defined as a 


\section{Entrepreneurship Education for Industrial Professional: The Influence of Communication, Teamwork, Leadership and Innovative Soft Skill on Job Performance}

response or ability to come up with novel and appropriate solution (Mumford, 2003) while innovation refers to the transformation of ideas or alternate solution into useful application (Carr \& Johansson, 1995).

Other discussed skills in the past literature include the followings;

- Analytical, Critical Thinking \& Problem Solving According to Gorgone, et al. (2002), analytical thinking leads to problem solving ability and critical thinking. It uses system concepts for comprehension and effectively identify solutions by framing the issues and thinking analytically to provide solution.

- Flexibility/Adaptability

Imply the willingness of employee to work with flexibly and able to adapt/tolerate the changes that revolves around the business.

\section{- Self-Awareness \& Management}

Self-awareness and management could be referred to an individual strength and effort to strive and build competency and addressing weaknesses Kanokorn, 2015).

\section{Performance of Engineers}

Performance is closely related to the delivery of targeted goals. The delivery could be measured in terms of quantity, quality, timeliness of output, attendance and/or efficiency in completing the assigned jobs (Mathis \& Jackson, 2010). For instance, performance of engineers in the oil and gas industry is often associated with the production output, safety achievement, financial optimization, projects deliverable and any other strategic initiatives.

In order to deliver outstanding performance, engineers need to inculcate more than just technical knowledge application as the delivery of performance takes multiple interaction process to meet the intended quantity, quality, timeliness and efficiency. As such, it is critical for the engineers to put all their skills on plate to overcome the challenges and deliver the targeted results. Often in challenging situation, they are also expected to come up quickly with mitigations and way forward for any surfaced issues hence reduced dependency on management to solve problems.

\section{METHODOLOGY}

The purpose of this study is to empirically investigate the relationship between entrepreneurial soft skills namely CTLI and engineer job performance. Using online survey questionnaire with Likert scale on statements relating to research constructs the study managed to collect 224 responds from graduate engineers working in oil and gas industry of East Malaysia where 20 responses have to be eliminated due to incompliances. Thus only 204 respondents are accepted for the analysis. To achieve the objective of this study, the data is analyzed using descriptive techniques and relationship between the antecedents of CTLI skills to job performance is assessed through correlation coefficient.

The correlation test is one of the most popular test applied in statistical studies. It is used to identify the relationship between two different variables or also known as bivariate analysis. The table of the correlation coefficient and corresponding strength of relationship is shown below in Table 1. Pearson correlation test is done to identify the correlation factor and the strength of relationship between engineers' soft skill attributes and performance. If there is no correlation exists, the variables could not be further tested for regression studies

Table 1: Correlation Coefficient and Strength of Relationship

\begin{tabular}{|c|c|}
\hline Correlation Coefficient & Strength Relationship \\
\hline 1 & Perfect \\
\hline $0.7<\mathrm{r}<1$ or $-0.7<\mathrm{r}<1$ & Strong \\
\hline $0.3<\mathrm{r}<0.7$ or $-0.3<\mathrm{r}<0.7$ & Moderate \\
\hline $0<\mathrm{r}<0.3$ or $0<\mathrm{r}<-0.3$ & Weak \\
\hline 0 & Zero \\
\hline
\end{tabular}

\section{DATA ANALYSIS AND RESULTS}

\section{Descriptive Analysis}

The descriptive analysis on respondents indicates those of aged between 23 to 30 years old makes up the majority $44.6 \%$ followed by respondents aged between 41 to 50 years old $(24 \%)$ took the survey. In the aspect of education, large group of respondents $(75 \%)$ have completed up to Bachelor's degree which is a mandatory requirement for engineering course. At the same time, 24\% of respondents have attained Master level of education with small percentage have completed their education up until $\mathrm{PhD}$ level. Regardless of age and education, all the respondents are currently working as engineer in the oil and gas industry.

The result on descriptive statistics on the soft skills attributes is shown in the following Table 2 where with descriptive indicators of mean, median, mode and standard deviation. Overall, based on the mean, the engineers have a good mastery over teamwork, communication skill, innovativeness and leadership by ranking of the data gathered from the 5 Likert scale responses related to each construct.

Table 2: Descriptive Statistic on Compounded Soft Skill Attributes

\begin{tabular}{|c|c|c|c|c|}
\hline \multirow{2}{*}{$\begin{array}{c}\text { Descriptiv } \\
\text { e Indicator }\end{array}$} & \multicolumn{4}{|c|}{ Compounded Variable } \\
\cline { 2 - 5 } & $\begin{array}{c}\text { Commun } \\
\text { ication }\end{array}$ & $\begin{array}{c}\text { Teamwor } \\
\mathrm{k}\end{array}$ & $\begin{array}{c}\text { Leaders } \\
\text { hip }\end{array}$ & $\begin{array}{c}\text { Innovativ } \\
\text { eness }\end{array}$ \\
\hline Mean & 3.9706 & 4.0172 & 3.8235 & 3.9510 \\
\hline Median & 4.0000 & 4.0000 & 3.6667 & 4.0000 \\
\hline Mode & 4.0000 & 4.00 & 4.00 & 4.00 \\
\hline $\begin{array}{c}\text { Standard } \\
\text { Deviation }\end{array}$ & 0.56133 & 0.57478 & 0.59776 & 0.49385 \\
\hline
\end{tabular}

This study aims to assess the influence of soft skill attributes towards engineers' performance based on the four CTLI related hypotheses. The summary of hypotheses and the results are shared in Table 3 . The $\mathrm{R}$ is a statistical figure similar to $\mathrm{r}$ which can be interpreted as a regular coefficient correlation value. The $\mathrm{R}$ indicates the strength of relationship between independent variable and dependent variable combined. In the case of relationships between Communication and Performance for example, the 
$\mathrm{R}$ value is 0.429 , reflecting the moderate positive relationship between communication soft skill and job performance. In the same table, $\mathrm{R}$ Square is showing value of 0.184 , indicating proportion of variation in the independent variable where in this case is the engineers' job performance. In other words, $18.4 \%$ of the variance in the data could be explained by communication. The relationship between Communication skill and Performance is significant at the 0.01 level (2-tailed) test. The same explanation applied for the other three variables of teamwork, leadership and innovativeness with different related values.

Table 3: Summary of Tested Hypotheses

\begin{tabular}{|c|c|c|}
\hline No & $\begin{array}{l}\text { Hypothesis and Model } \\
\text { Summary: } \\
\text { R } \\
\text { R Square } \\
\text { Adjusted R Square } \\
\text { Standard Error of the Estimate }\end{array}$ & $\begin{array}{l}\text { Results: } \\
\text { Fail to } \\
\text { Reject/Reject } \\
\text { Pearson } \\
\text { Correlation } \\
\text { Sig (2 tailed) at } \\
\text { N }\end{array}$ \\
\hline 1 & $\begin{array}{l}\text { Communication skill influence } \\
\text { engineers' performance. } \\
\mathrm{R}=.429^{\mathrm{a}} \\
\mathrm{R} \text { Square }=.184 \\
\text { Adjusted R Square }=.180 \\
\text { Standard Error of the } \\
\text { Estimate }=.51940\end{array}$ & $\begin{array}{l}\text { Fail to reject } \\
\text { Pearson } \\
\text { Correlation }=.429 \\
* * \\
\text { Sig (2 tailed }) \\
\text { at }=.000 \\
\mathrm{~N}=204\end{array}$ \\
\hline 2 & $\begin{array}{l}\text { Teamwork influence engineers' } \\
\text { performance. } \\
\mathrm{R}=.418^{\mathrm{a}} \\
\mathrm{R} \text { Square }=.175 \\
\text { Adjusted R Square }=.171 \\
\text { Standard Error of the } \\
\text { Estimate }=.52215\end{array}$ & $\begin{array}{l}\text { Fail to reject } \\
\text { Pearson } \\
\text { Correlation }=.418 \\
* * \\
\text { Sig } \quad(2 \quad \text { tailed }) \\
\text { at }=.000 \\
\mathrm{~N}=204\end{array}$ \\
\hline 3 & $\begin{array}{l}\text { Leadership influence engineers' } \\
\text { performance. } \\
\mathrm{R}=.475^{\mathrm{a}} \\
\mathrm{R} \text { Square }=.225 \\
\text { Adjusted R Square }=.222 \\
\text { Standard Error of the } \\
\text { Estimate }=.50598\end{array}$ & $\begin{array}{l}\text { Fail to reject } \\
\text { Pearson } \\
\text { Correlation }=.475 \\
* * \\
\text { Sig } \quad(2 \quad \text { tailed }) \\
\text { at }=.000 \\
\mathrm{~N}=204\end{array}$ \\
\hline 4 & $\begin{array}{l}\text { Innovativeness influences } \\
\text { engineers' performance. } \\
\mathrm{R}=.528^{\mathrm{a}} \\
\mathrm{R} \text { Square }=.279 \\
\text { Adjusted R Square }=.275 \\
\text { Standard Error of the } \\
\text { Estimate }=.48820\end{array}$ & $\begin{array}{l}\text { Fail to reject } \\
\text { Pearson } \\
\text { Correlation }=.528 \\
* * \\
\text { Sig } \quad(2 \quad \text { tailed }) \\
\text { at }=.000 \\
\mathrm{~N}=204\end{array}$ \\
\hline
\end{tabular}

Table 4 below illustrates the model summary based on the regression analysis applied in this research. The independent variables namely communication skill, teamwork, leadership, and innovativeness are grouped together to assess its impact on the dependent variable of engineers' job performance. The outcome is shown in the table below.
Table 4: Model Summary

\begin{tabular}{|l|l|l|l|l|}
\hline \multicolumn{2}{|l|}{ Model Summary } \\
\hline Model & $\mathrm{R}$ & R Square & $\begin{array}{l}\text { Adjusted } \\
\text { Square }\end{array}$ & $\begin{array}{l}\text { R Std. Error of the } \\
\text { Estimate }\end{array}$ \\
\hline 1 & $.582^{\mathrm{a}}$ & .338 & .325 & .47115 \\
\hline
\end{tabular}

a. Predictors: (Constant), Creativity \& Innovation, Teamwork, Leadership, Communication Skill

b. Dependent Variable: Performance

The $\mathrm{R}$ value is 0.582 reflecting the moderate relationship existence between the grouped soft skill and job performance. The R-square indicates that around $33.8 \%$ variance in performance result is contributed by soft skills. ANOVA result suggests that soft skill is a significant predictor of engineers' performance, F $(4,199)=25.44$, $\mathrm{p}=0.000$. The unstandardized and standardized beta coefficients indicate positive relationship between grouped CTLI soft skill and engineers' performance. From the coefficients findings, the most significant dependent variables that are affecting performance are innovativeness followed by leadership qualities. This indicates that among the four soft skill attributes, two particular traits have biggest impact when they are lumped together under one umbrella of CTLI soft skill.

\section{DISCUSSIONS - SOFT SKILL INFLUENCE ON Engineers' Performance}

\section{Communication Skill Influence Engineers' Performance}

The finding shows there is a significant relationship between communication skill and engineers' performance. There are few other studies that support the influence of communication skill on performance. For instance, a study performed on employees from selected organization in Nigeria revealed that there is relationship exist between effective communication and employees' performance, productivity and commitment (Femi, 2014). Similarly, on the same subject, it was evident that the synergistic relationship exists between effective communication and organizational performance (Shonubi \& Akintaro, 2016). Overall, contribution of communication skill is significant and could not be easily eliminated especially when the pool of talents or engineers hired into the company are having equal technical competency. As such, engineers' should continuously work towards strengthening their communication skill and able to direct their ideas appropriately.

\section{Teamwork Influence Engineers' Performance}

The second hypothesis intends to evaluate whether teamwork has any influence on engineers' performance. Based on the results obtained, the p-value of zero reflects teamwork skill as a significant predictor of engineers' performance. The impact of teamwork on performance has been discussed by other researches too. For instance, a study revealed that there is significant connection between teamwork of faculty members and their performance where teamwork enriches productivity of their jobs (Sanyal \& Hisam, 2018). Collaborating with multiple parties helps to expand the knowledge and also keep the engineers updated on 


\section{Entrepreneurship Education for Industrial Professional: The Influence of Communication, Teamwork, Leadership and Innovative Soft Skill on Job Performance}

any issues. The latter is very much valued by managers as the engineers who are always on top of problems are seen as a reliable focal to manage the problem without requiring much attention and intervention from the managers. Indirectly, this creates good impression and contributes on the engineers' overall performance at work.

\section{Leadership Influence Engineers' Performance}

Hypothesis number 3 aimed to investigate whether leadership has any influence on engineers' performance. As per the output of regression analysis in previous chapter, there is a positive relationship between engineers' leadership ability and their performance at work. Many researchers have focused in assessing management leadership style and their effect on employees' performance. For instance, a study conducted on Petro Vietnam Engineering Consultancy leaders' attitude shows positively strong significance towards employees' performance (Thao \& Hwang, 2011). Similarly, another study carried out in Malaysia also indicates that there is a significant and positive impact of democratic and laissez-faire leadership styles on employee performance (Basit, Sebastian, \& Hassan, 2017). Engineers' that are able to portray good leadership skill will be influential and attract many opportunities for future grow and development.

\section{Innovativeness (creativity and innovation) Influence Engineers' Performance}

The last hypothesis tested is aimed to assess whether creativity and innovation influence engineers' performance. Results obtained illustrates that creativity and innovation is a significant predictor for engineers' performance results. The impact of creativity and innovation on performance has been discussed by other researchers as well. An empirical study conducted in Portugal found that creativity significantly and positively affect organization performance (Ferreira, Coelho, \& Moutinho, 2017). In another research, it was examined and concluded that creativity and innovation is positively related to task performance (Michael, Reaves, \& Viswesvaran, 2016). Creativity and innovation is a fundamental element in the engineering line. While creativity generates novel solution, innovation creatives improved solution.

\section{CONCLUSION}

One of the challenges of Industry 4.0 is to have the industry and the academia act as one to fulfil industry and graduate needs. The role of higher education institutions is to prepare students for the changes brought by Industry 4.0. Higher education institutions are still facing difficulties in implementing entrepreneurship education effectively. Major issues identified are the commitment towards entrepreneurship education by both educators and students, lacking of proper entrepreneurship training for educators as well as insufficient educators' qualification and curriculum exposures (Rahim et.al.2015) particularly in producing professional practice workforce. This study has shed lights on the entrepreneurial qualities in terms of CTLI soft kills which should be given priorities by entrepreneurship educators in Education 4.0. Among the four soft skill attributes, it was noted that innovativeness has higher significance towards engineers' performance. The importance of this particular soft skill attribute could not be ignored as creativity and innovative behavior is the key for problem solving in an organization. It involves finding new ideas, shaping and defining the concept which helps a company to overcome challenges and progress forward. Thus, it is expected that engineers who are creative and innovative would yield better performance than the others as innovation is critical in Industry 4.0.

This study just focused on four important skills namely CTLI for professional workforce in engineering sector. Although it will be a great challenge for educators to integrate the soft skills or qualities of CTLI in the traditional field of knowledge within the IR4.0 framework, the integration of CTLI experience through entrepreneurship education would produce better equipped technical graduates. Future studies may be expanded to go deeper on workforce attributes for Industry 4.0. For example, the communication focus can be expanded into mobile communications as well as social media presence. Teamwork should include global networking while leadership should go beyond boundaries.

\section{ACKNOWLEDGMENT}

This research is made possible via Transdisciplinary Grant by Universiti Teknologi Malaysia under UTM-TDR 2.4 (T1): Entrepreneurship Quality within Industrial Professional Practice Workforce Vote: Q K130000.3555.053G10.

\section{REFERENCES}

1. Abdul Haseeb, (2018), Higher Education in the Era of IR 4.0, News Straits Times. Available: https://www2.nst.com.my/education/2018/01/323591/highereducation-era-ir-4.0

2. Alfan, E., \& Othman, M. (2005). Undergraduate Students' Performance: The Case of University Malaya. Quality Assurance in Education, Vol.13, No 4, pp. 329-43.

3. Basit, A., Sebastian, V., \& Hassan, Z. (2017). Impact of Leadership Style on Employee Performance (A Case Study on a Private Organization in Malaysia). International Journal of Accounting \& Business Management, Vol. 5 (2). pp. 112-130

4. Carr, D. K., \& Johansson, H. J. (1995). Best Practices in Reengineering: What Works and What Doesn't in the Reengineering Process. New York: McGraw-Hill pp.11-25

5. Darmi, R., \& Albion, P. (2013). Malaysian Graduates: What and Why. 3rd Malaysian Postgraduate Conference (MPC2013). 3-4 Jul, Sydney, New South Wales, Australia

6. Duval-Couetil, Nathalie (2013), Assessing the Impact of Entrepreneurship Education Programs: Challenges and Approaches (July 2013). Journal of Small Business Management, Vol. 51, Issue 3, pp. 394-409

7. Femi, A. F. (2014). The Impact of Communication on Workers' Performance in Selected Organisations in Lagos State, Nigeria. IOSR Journal of Humanities And Social Science (IOSR-JHSS), Volume 19 Issue 8, pp. 75-82.

8. Ferreira, J., Coelho, A., \& Moutinho, L. (2017). Dynamic Capabilities, Creativity and Innovation Capability and Their Impact on Competitive Advantage and Firm Performance: The Moderating Role of Entrepreneurial Orientation Available: https://doi.org/10.1016/j.technovation.2018.11.004

9. Gorgone, J. T., Davis, G. B., Valacich , J. S., Topi, H., Feinstein , D. L., \& Longenecker, Jr, H. E. (2002). Is 2002-Model Curriculum \& Guidelines for Undergraduate Degree Programs Information in Systems. https://www.acm.org/binaries/content/assets/education/curricularecommendations/is2002.pdf

10. Hanapi, Z., \& Nordin, M. S (2014). Unemployment among Malaysia Graduates: Graduates'attributes, 
Lecturers'competency and Quality of Education. International Conference on Education \& Educational Psychology 2013 (ICEEPSY 2013). Procedia - Social and Behavioral Sciences, pp: $1056-1063$.

11. Hendarmana, A. F., \& Tjakraatmadjab, J. H. (2012). Relationship among Soft Skills, Hard Skills, and Innovativeness of Knowledge Workers in the Knowledge. Procedia - Social and Behavioral Sciences (52), $35-44$

12. Hoo, Q. C., Nasurdin, A., Chai, G. E., \& Ignatius, J. (2009) Employers' Preference for Foreign Trained Graduates - Myth European Journal of Scientific Research, ISSN 1450-216X Vol.34 No.3 (2009), pp.372-383.

13. Jobstreet. (13 November, 2017). 5 soft skills you need to master, to stand out as an engineer. Available: https://www.jobstreet.com.my/career-resources/5-soft-skills-needmaster-stand-engineer/\#.XAI_EWgzZPY

14. Junaidah Hashim. (2012). Higher Education, Skills and Work-Based Learning: Academic Excellence as Selection Criteria among Malaysian Employers. Vol. 2 Iss 1 pp. 63 - 73.

15. Leaderonomics, (2017). SL1M: Graduated With A PhD But Jobless? Here's Why. Retrieved from Leaderonomics.com: Available: https://leaderonomics.com/business/sl1 m-graduated-but-jobless

16. Mathis, R. L., \& Jackson, J. H. (2010). Human Resource Management. Ohio.: 13th Edition, South-Western College Publishing. pp. 327

17. Michael , H. B., Reaves, A. C., \& Viswesvaran, C. (2016). Creative and Innovative Performance: A Meta-Analysis of Relationships with Task, Citizenship, and Counterproductive Job Performance Dimensions. European Journal of Work and Organizational Psychology, 25:4, pp. 495-511.

18. Mumford, M. D. (2003). Where Have We Been, Where Are We Going? Taking Stock in Creativity Research. Creativity Research Journal, (15), pp.107-120.

19. New Straits Times, (2018). Retrieved from Graduate skills gap: Available:

https://www.nst.com.my/education/2018/10/417327/graduate-skillsgap

20. Ngang, T. K., Mohamed, S. H., \& Kanokorn, S. (2015). Soft Skills of Leaders And School Improvement In High Performing Schools. Procedia - Social and Behavioral Sciences, pp. 2127 - 2131.

21. Nik Hairi et al. (2012). Graduates' Employability Skills Based on Current Job Demand. Asian Social Science, Vol. 8, No. 9. pp. 103 110

22. Okudan G.E and Rzasa S.E (2004) A Project-Based Approach to Entrepreneurial Leadership Education, Technovation, Vol 26, Issue 2 pp. $195-210$

23. QAA (2012), Enterprise and entrepreneurship education: Guidance for UK higher education provider. Avail;able: https://www.qaa.ac.uk/docs/qaas/enhancement-anddevelopment/enterprise-and-entrpreneurship-education2018.pdf?sfvrsn=15f1 f981_8

24. Rahim, H. L., Mohtar, S. \& Ramli, A. (2015). The Effect of Social Entrepreneurial Behavior towards Organizational Performance: A Study on Bumiputera Entrepreneurs in Malaysia. International Academic Research Journal of Business and Technology 1(2), pp. 117-125.

25. Rainsbury, E., Hodges, D., \& Burchell, N. (2001). Ranking Workplace Competencies: Student and Graduate Perceptions. AsiaPacific Journal Cooperative Education, 3(2), pp. 8-18.

26. Sani, R. (2018). Entrepreneurial Ecosystems at the University, Available:

https://www.nst.com.my/education/2018/01/323599/entrepreneurialecosystems-university

27. Sanyal, S., \& Hisam, M. W. (2018). The Impact of Teamwork on Work Performance of Employees: A Study of Faculty Members in Dhofar University. IOSR Journal of Business and Management (IOSR-JBM), Volume 20, Issue 3. Ver. I, pp. 15-22.

28. Shakir, R. (2007). Soft skills at the Malaysian institutes of higher learning. Asia Pacific Educ. Rev. (2009) 10: pp. 309-315.

29. Shonubi, A. O., \& Akintaro, A. A. (2016). The Impact of Effective Communication On Organizational Performance. The International Journal of Social Sciences and Humanities Invention, Volume 3 issue 3 pp.1904-1914.

30. Sisodia, S., \& Agarwal, N. (2017). Employability Skills Essential for Healthcare Industry. Information Technology and Quantitative Management (ITQM 2017), Procedia Computer Science (122), pp. $431-438$.

31. TalentCorp Malaysia. (2014). Matching Talent to Jobs - Trends in Graduate Employability. Available:
https://www.talentcorp.com.my/clients/TalentCorp_2016_7A6571AE -D9D0-4175-B35D-

99EC514F2D24/contentms/img/publication/Matching-Talent-to-Job1.pdf

32. Thao, L. T., \& Hwang, C.-s. J. (2011). Factors Affecting Employee Performance-Evidence from Petrovietnam Engineering Consultancy J.S.C. International Journal of Project Management Vol 29 (1) pp 112

33. The Malaysian Insight. (17 July, 2018). Malaysia Needs 7 Times More Scientists, Engineers by 2020, says Hannah Yeoh. Availabe: https://www.themalaysianinsight.com/s/78386

34. The Sun Daily. (7 September, 2017). Malaysia Not Churning Out Suitable Graduates for Innovation, R\&D: Professor. Available: https://www.thesundaily.my/archive/malaysia-not-churning-outsuitable-graduates-innovation-rd-professor-IT ARCH479613

35. Williams, A.-M. C. (2015). Soft Skills Perceived by Students and Employers as Relevant Employability Skill. Walden Dissertations and Doctoral Studies, pp. 14.

36. Yahaya, A., Maalip, H., Yahaya, N., \& Theng, L. T. (2018) Hubungan Gaya Kepimpinan Guru Besar Dengan Faktor- Faktor Kepimpinan Di Sekolah Cemerlang. Journal of Education Management 1(4), pp.1-23.

37. Yorke, M., \& Knight, P. (2006). Embedding Employability into the Curriculum. Higher Education Academy York. 3. Higher Education Academy York. Available: https://www.heacademy.ac.uk/resource/embedding-employabilitycurriculum

38. Yuzainee, M. Y., Omar, M. Z., \& Zaharim, A. (2010). Employability Skills for an Entry-Level Engineer as seen by Malaysian Employers. IEEE Global Engineering Education Conference (EDUCON) "Learning Environments and Ecosystems in Engineering Education. Amman, Jordan. pp. 559

39. Zaharima, A., Ahmadb, I., Yusoff, Y. M., \& Omarc, M. Z. (2012) Evaluating the Soft Skills Performed by Applicants of Malaysian. Procedia - Social and Behavioral Sciences (60), pp. 522 - 528. 